\title{
Physical and mechanical properties of cement mortar made with brick waste
}

\author{
Guendouz Mohamed ${ }^{1}$, Boukhelkhal Djamila ${ }^{1}$ \\ ${ }^{1}$ LME Laboratory, University of Medea, Medea, Algeria
}

\begin{abstract}
The development of new building materials is a current problem where researchers are trying to find the right materials for each region and returning cheapest countries. Recycling and recovery of waste are now considered as a promising solution to meet the deficit between production and consumption and protecting the environment. This work focused on the study of the effect of brick waste in the production of cement mortar with substitution rates ranging from $5-30 \%$ by weight of cement and to compare its performance with fresh and hardened state with ordinary mortar considered as control mortar. Compressive and tensile strengths up to 28 days of age were compared with those of controlled mortar. Water absorption was also measured at 28 days of age. The test results indicate the beneficial effect of brick waste powder on performance of cement mortar with an optimum of $15 \%$ of cement weight substitution.
\end{abstract}

\section{Introduction}

The manufacturing of cement, mortar and concrete, as is the case with many industrial materials, consumes a considerable amount of energy, generates large quantities of greenhouse gases (estimated today to 1 tone of $\mathrm{CO}_{2}$ per 1 tone of cement produced in the world), contributes to the gradual depletion of natural resources and leads to the production of certain residues which must be eliminated.

In order to ensure the growth of these indispensable building materials, the sustainable development approach must be integrated into their production, thus achieving a balance between environmental protection constraints and economic and social considerations [1-5]. Therefore, in view of the increasing need for materials resources and the need to preserve the environment in a sustainable development vision, it has become necessary and relevant to explore all possibilities for reuse and recovery of waste and - industrial products, particularly in the field of civil engineering. However the waste storage disposals are becoming also a serious environmental problem, especially for main cities where disposal sites are lacking. Wastes from construction materials, materials factories, demolition sites, earthquakes and natural disasters are until now rarely used in Algeria: there is hence a need for recycling more and more waste materials.

The need to find new and cheaper binders has led manufacturers to produce various cements containing in addition to clinker, secondary additions with varying proportions. In Algeria, blast furnace slag and pozzolana are used as an additive to cement. Other local materials can also be used and valorized. And it is in this context that our study takes place. It aims to develop new composite cement based on brick waste and having a strength class of $42.5 \mathrm{MPa}$. These by-products of the red products industry, which remain little used or recycled so far, are relatively abundant in Algeria because of the high number of brickyards and the discharge rates (noncompliant or broken bricks) They generate and account for 10 to $15 \%$ of their productions $[6,7]$.

The terracotta products are really very durable and their resistance to the test proves it. Moreover, studies carried out by several researchers have shown the beneficial effect of the use of this type of waste [8-11] in addition to the pozzolanic character of the latter $[8,12$ 16].

The objective of this work is to study the effect on physical and mechanical properties of mortar made with fine crushed brick waste powder. Cement is substituted by weight by bricks waste powder at rates varying from $0,5,10,15,20,25$ and 30\%. Compressive and tensile strengths are evaluated and compared up to 28 days of age. Capillary water absorption is also measured at 28 days of age

\section{Experimental}

\subsection{Materials}

Portland Composite Cement based on limestone (CEM II/A 42.5) with a fineness of $3080 \mathrm{~cm}^{2} / \mathrm{g}$ and a specific gravity of $2.93 \mathrm{~g} / \mathrm{cm}^{3}$ was used in this study. Its average compressive strength at 28 days is $46.43 \mathrm{MPa}$. 
The powder used in the manufacturing of cement mortar derives from the brick waste from the brickworks of Draa Smar in Médéa. Once the waste was received, it was crushed by a laboratory jaw crusher which allowed us to obtain a material whose grain size is $0-5 \mathrm{~mm}$. After they are placed in a disk mill to convert them into fine powder, with fineness comparable to that of the cement used $\left(3500 \mathrm{~cm}^{2} / \mathrm{g}\right)$. Its absolute density has a value of $2.66 \mathrm{~g} / \mathrm{cm}^{3}$.

For the fineness modulus of sand used is about 2.50, we combined two sands: 0/3 roller siliceous sand (S1) from the region of Hassi Bahbah (28\%) and 0/4 crushed limestone sand (S2) from the quarry of Mont Guorno (72\%). The grain size distribution of roller and crushed sand is presented in "figure 1" and their physical properties are summarized in Table 1. To ensure satisfactory workability of the brick waste-based mortars, a water-reducing plasticizer adjuvant manufactured by the company Granitex-NP and marketed under the name "MEDAFLOW 145" was used in this study which does not exhibit a retarding effect. Its normal range of use is fixed by the data sheet of 0.3 to $2 \%$ of cement weight, and its specific gravity is of $1.06 \mathrm{~g} / \mathrm{cm}^{3}$.

Table 1. Physical properties of sand used.

\begin{tabular}{|c|c|c|c|}
\hline Properties & $\begin{array}{c}\text { Roller } \\
\text { sand }\end{array}$ & $\begin{array}{c}\text { Crushed } \\
\text { sand }\end{array}$ & \multirow{2}{*}{ Standard } \\
\hline Granular class & $0 / 3$ & $0 / 5$ & \\
\hline Fineness Modulus & 1.06 & 3.45 & $\begin{array}{c}\text { NF EN 933-1 } \\
{[17]}\end{array}$ \\
\hline $\begin{array}{c}\text { Specific gravity } \\
\left(\mathrm{g} / \mathrm{cm}^{3}\right)\end{array}$ & 2.58 & 2.59 & $\begin{array}{c}\text { NF EN 1097-6 } \\
{[18]}\end{array}$ \\
\hline $\begin{array}{c}\text { Bulk density } \\
\left(\mathrm{g} / \mathrm{cm}^{3}\right)\end{array}$ & 1.42 & 1.48 & $\begin{array}{c}\text { NF EN 1097-3 } \\
{[19]}\end{array}$ \\
\hline $\begin{array}{c}\text { Sand equivalent } \\
(\%)\end{array}$ & 61.13 & 71.31 & $\begin{array}{c}\text { NF EN 933-8 } \\
{[20]}\end{array}$ \\
\hline $\begin{array}{c}\text { Water absorption } \\
(\%)\end{array}$ & 0.40 & 0.30 & $\begin{array}{c}\text { NF EN 1097-6 } \\
{[18]}\end{array}$ \\
\hline
\end{tabular}

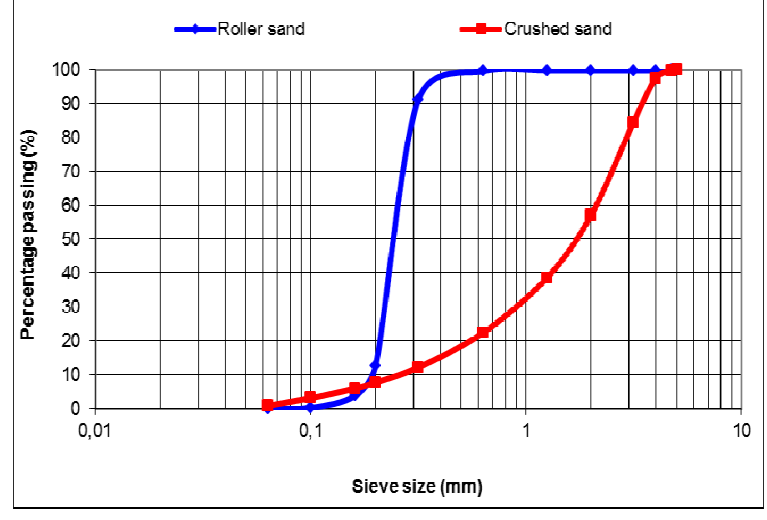

Fig. 1. Particle size distribution of used sand and coffee waste.

\subsection{Mix design}

For the purpose of this study, a reference mortar is made from $100 \%$ cement named MT. And seven (07) other mixtures are prepared by replacing the cement by different $\%$ of brick waste $(5,10,15,20,25$ and $30 \%)$.

In order to determine the quantities of The different materials: sand, cement, water and plasticizer of this mortar, we based on the standard formulation method for normal mortar $(\mathrm{S} / \mathrm{C}=3$ et $\mathrm{W} / \mathrm{C}=0.5)$ [21], with some modifications made in the determination of water to cement ratio $(\mathrm{W} / \mathrm{C}=0.54)$ in order to adapt the requirements of local materials, taking into account their absorption rate and to get a good plasticity of mortar in fresh state.

The composition adopted for the control mortar and the mortars based on brick waste is that corresponding to the composition which gave satisfactory workability and comparable to that for a normal sand-based mortar (Flow time in LCPC maneabilimeter is close to 10 seconds) [22]. The optimum compositions of the various mixtures are shown in Table 2.

Table 2. Mix proportion of mortar mixes

\begin{tabular}{|c|c|c|c|c|c|c|}
\hline \multirow{2}{*}{$\begin{array}{c}\text { Constituent } \\
\left(\mathrm{kg} / \mathrm{m}^{3}\right)\end{array}$} & \multirow{2}{*}{$\mathbf{C}^{1}$} & \multirow{2}{*}{$\mathbf{B W}^{2}$} & \multicolumn{2}{|c|}{ Sand } & \multirow{2}{*}{ W } & \multirow{2}{*}{$\mathbf{P s}^{3}$} \\
\hline & & & S1 & S2 & & \\
\hline MT & 450 & 0 & 978 & 372 & 243 & 0 \\
\hline $\operatorname{MBr} 5 \%$ & 427 & 22.5 & 978 & 372 & 243 & 0 \\
\hline MBr10\% & 405 & 45 & 978 & 372 & 243 & 0.10 \\
\hline MBr $15 \%$ & 382 & 67.5 & 978 & 372 & 243 & 0.10 \\
\hline MBr $20 \%$ & 360 & 90 & 978 & 372 & 243 & 0.12 \\
\hline MBr $25 \%$ & 337 & 112 & 978 & 372 & 243 & 0.15 \\
\hline MBr 30\% & 315 & 135 & 978 & 372 & 243 & 0.20 \\
\hline
\end{tabular}

\section{Results and discussion}

\subsection{Characterization of mortar mixes in fresh state}

Preliminary tests on non-adjuvant brick waste mortars have shown that this waste adversely affects the workability of mortar in LCPC maniabilimeter [22], which confirms the results found by several researchers $[23-25,12]$. This decrease in workability appears due to the high rate of absorption of brick waste in addition to the irregular shape of its grains [26].

In order to be able to compare the different types of brick waste mortar with the control mortar, the mixtures must have the same workability. This requires the reformulation of the mortars with brick waste. For this, we used a plasticizer admixture to keep the same flow time of the brick mortars with the control mortar. 
The admixture need for the different mortars is shown in "figure 2". It can be seen that the demand of plasticizer in brick waste mortars increases with the increase in the percentage of waste in the mortar.

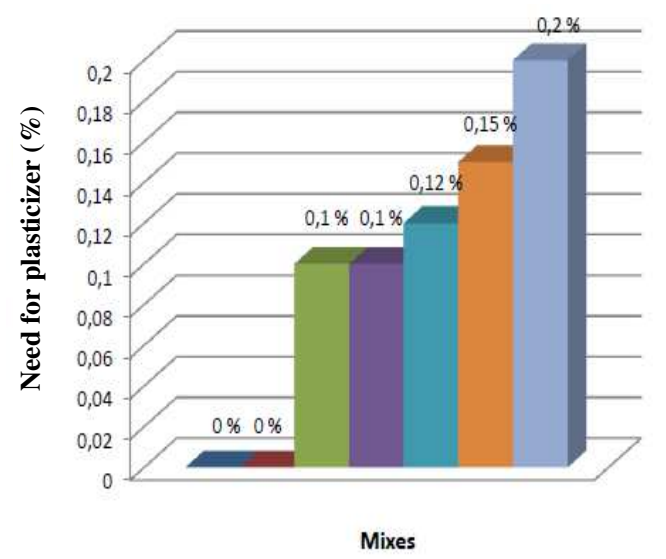

IMT

$\mathrm{MBr} 5 \%$

MBr $10 \%$

- $\operatorname{MBr} 15 \%$

MBr $20 \%$

$=\mathrm{MBr} 25 \%$

InBr $30 \%$

Fig.2. Need of plasticizer admixture for mortar with brick waste.

\subsection{Characterization of mortar mixes in hardened state}

\subsubsection{Mechanical strength}

In order to better understand the relative evolution of compressive and tensile strength of the different mortars with age and in function of the rate of substitution of brick waste and to allow comparison with the control mortar, we present this evolution under histogram form given in "figure 3" and "figure 4". respectively.

The first point to be emphasized in these figures is that, at a young age, the resistance of mortars based on brick waste decreases with the increase in the rate of substitution in waste. It is also noted that mechanical performance develops in the early days of hydration. Figure 3 also shows that the resistances of all mortars increase steadily with age and show no fall. It is also observed that the initial resistances of the various mortars (at 3 days) reach $50 \%$ compared to that of the 28 days.

At the age of 28 days, the strength of mortars $\mathrm{MBr} 5 \%$, $\mathrm{MBr} 10 \%$ and $\mathrm{MBr} 15 \%$ exceed that of the reference mortar which is probably due to the pozzolanic activity of this material according other researchers [12-16].

\subsubsection{Water absorption}

The results of capillary water absorption test for mortars mixes carried out are summarized in "figure 5". This figure shows that the mortar based on the brick waste absorbs less water than the control concrete. This it may be due to the pozzolanic reactions of brick waste which have improved the compactness of mortar structure.

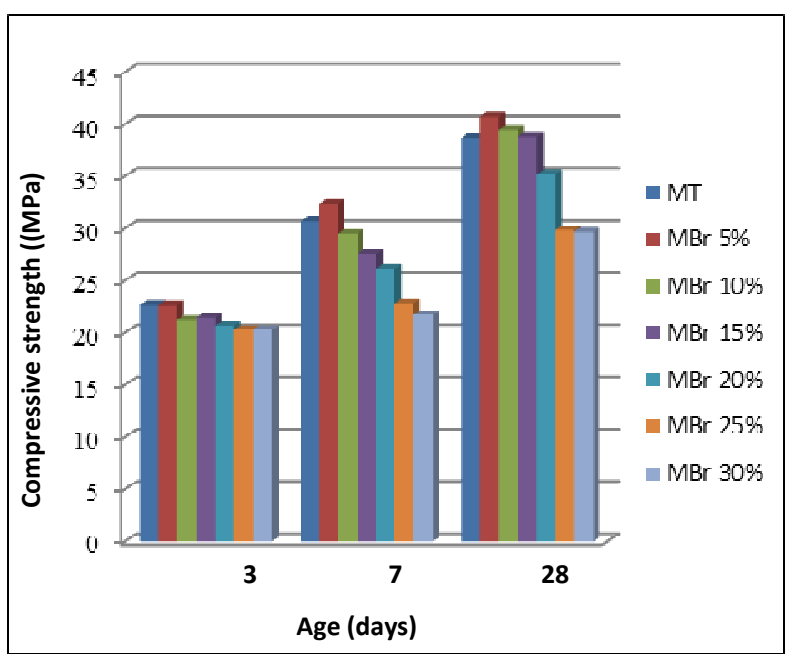

Fig.3. Compressive strength for mortar brick waste.

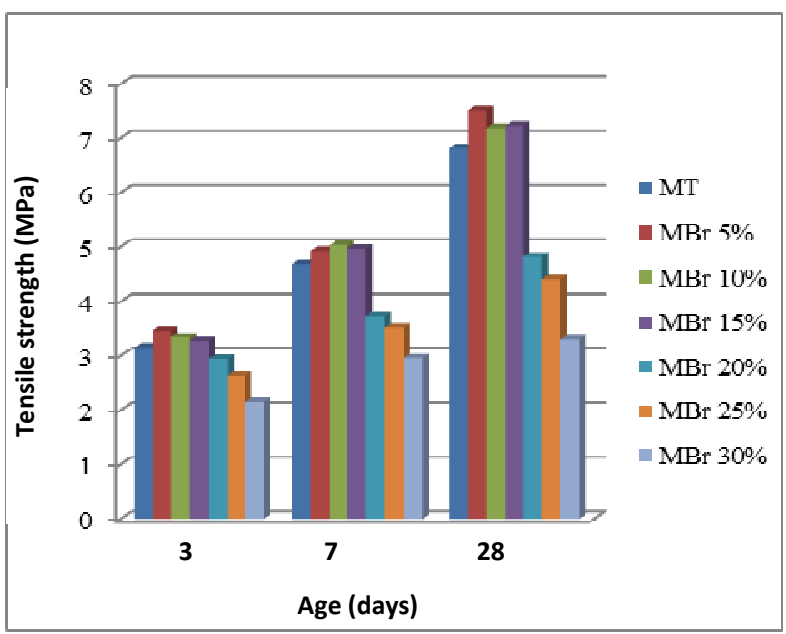

Fig. 4. Flexural strength for mortar brick waste.

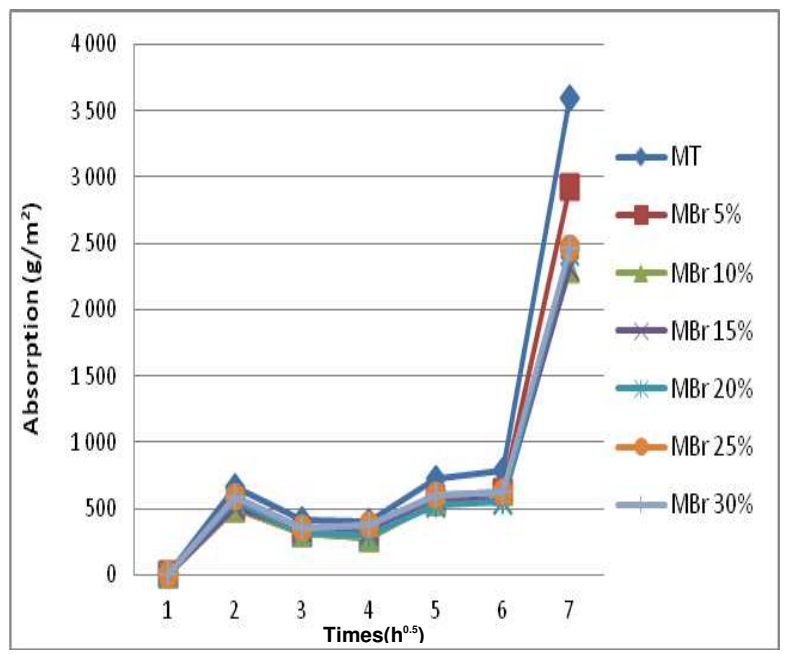

Fig.5. Capillarity water absorption for brick waste based mortars. 


\section{Conclusions}

The main objective of this work was to evaluate brick waste in the manufacture of cement mortars. For this purpose, the study is based on the comparison of the behavior of ordinary mortar with those of mortars based on brick waste powder with constant workability. Based on the results obtained through this study, the following conclusions have been drawn:

- The finely ground brick powder has a negative influence on the workability of the mortar as a function of the cement substitution rate,

- In hardened state the brick waste powder plays both a double pozzolanic role and a densification of the cementitious matrix. Improvements in the mechanical performance of mortars were observed from 28 days of age for substitution rates of 5, 10 and $15 \%$ of the cement weight compared to the control mortar,

- The addition of brick waste powder reduces the absorption rate by capillarity;

- The results obtained show that brick waste can be technically used as a cement substitute in the manufacture of ordinary mortars

\section{References}

1. L. Courard, Valorisation des déchets et sous-produits dans le génie civil, notes de cours, Univ Liège, (1998), 195p.

2. J. S. Damtoft, J. Lukasik, D. Herfort, D. Sorrentino and E. M. Gartner, Sustainable development and climate change initiative, Cem. Concr. Res., 38 (2008), pp. 115-27.

3. M. Guendouz, F. Debieb, O. Boukendakdji, E. H. Kadri, M. Bentchikou and H. Soualhi, J. Meter. and Env. Scien., 7(2), (2016), 227-232.

4. I. Martínez, M Etxeberria, E Pavón.,N. Díaz, , Constr and Build Mater J., Vol. 49(2013), pp. 384392.

5. M. Guendouz, F. Debieb and E. H. Kadri, 33èmes roncontres de l'AUGC, ISABTP/UPPA, Anglet, 27 au 29 Mai 2015, Bayonne, France, (2015), p. 1-8.

6. V. Corinaldesi, M. Giuggiolini and G. Moriconi, Use of rubble from building demolition in mortars, Waste Manage, Vol. 22 (2002) pp. 893-902.

7. Y. Jian ,D. Qiang ,B. Yiwang, Concrete with recycled concrete aggregate and crushed clay bricks, J Constr and Build Mater., Vol. 25(2011), pp. 19351945.

8. Fédération national Belge de la brique, Fabrication de la brique, Brique de parement, Blocs treillis, brique de pavages,...des produits naturels en terre cuite.

9. F. Debieb and S. Kenai, J. Constr. and Build. Mater., 22(2008), pp. 886-893.

10. S. Kenai and F. Debieb, J. of Materials and Structures, 44(2011), pp. 815-824.
11. Z. Lan, F. Zhengyue and Z. Shiping, Permeability of recycled aggregate concrete containing fly ash and clay brick waste, Department of Architecture and Civil Engineering, Nanjing Institute of Technology (2014), China.

12. M. S. Dina, Physico-mechanical properties of solid cement bricks containing recycled aggregates, J. Building Materials Research and Quality Control Institute, Housing and Building National Research Center, Egypt (2011).

13. M. Hadjoudja and M. Bederina, Influence des fillers des déchets de briques sur la durabilité à l'eau du béton de sable de dunes, Université de Laghouat (2005), Algérie .

14. CIM béton, Fiche technique édité par le centre d'information sur le ciment et ses applications : « Les mortiers », Tome 3 (2008), Paris, France.

15. F. Bektas, K. Wang and H. Ceylan, Effects of crushed clay brick aggregate on mortar durability, Civil Construction and Environmental Engineering, Iowa State University, United States (2008).

16. G. Nigri, Y. Cherait and H. Benouis, Valorisation des déchets de briques dans l'industrie cimentaire, Séminaire International INVACO2, (2011), Rabat, Maroc.

17. NF EN 933-1, Essais pour déterminer les caractéristiques géométriques des granulats. Partie 1: Détermination de la granularité. Analyse granulométrique par tamisage, AFNOR (1997).

18. NF EN 1097-6, Essais pour déterminer les caractéristiques mécaniques et physiques des granulats. Partie 6: Détermination de la masse volumique réelle et du coefficient d'absorption d'eau, AFNOR (2001).

19. NF EN 1097-3, Essais pour déterminer les caractéristiques mécaniques et physiques des granulats. Partie 3: Méthode pour la détermination de la masse volumique en vrac et de la porosité intergranulaire, AFNOR (1998).

20. NF EN 933-8, Essais pour déterminer les caractéristiques géométriques des granulats. Partie 8: Evaluation des fines. Equivalent de sable, AFNOR (1999).

21. NF EN 1008, Eau de gâchage pour bétons: spécification d'échantillonnage, d'essais et d'évaluation de l'aptitude à l'emploi, y compris les eaux des processus de l'industrie du béton, telle que l'eau de gâchage pour béton, AFNOR (2003).

22. NF P 18-452, Béton- mesure du temps d'écoulement des bétons et des mortiers aux maniabilimètre LCPC, AFNOR (1988).

23. NF EN 196-2, Méthodes d'essais des ciment- Partie 2: Analyse chimique des ciments, AFNOR. 46 p. (2006).

24. B. Étienne and D. Georges-Bernard, Règlements sur les arts et métiers de Paris, rédigés au $13^{\mathrm{e}}$ siècle, et connus sous le nom du Livre des métiers d'Étienne Boileau. Crapelet (1837).

25. M. Augustin, Ciment and mortar, Libr. Armand Colin, coll., Génie civil, (1935), p. 2. 
26. N. Bourmatte, Granulats recyclés de substitution pour bétons hydrauliques, thèse de magister, Université de Constantine, Algérie (2004). 